\title{
ANALISIS PERBANDINGAN PERFORMA VIRTUALISASI SERVER SEBAGAI BASIS LAYANAN INFRASTRUCTURE AS A SERVICE PADA JARINGAN CLOUD
}

\author{
Deni Marta ${ }^{1}$, M. Angga Eka Putra ${ }^{2}$, Guntoro Barovih ${ }^{3}$ \\ 1,2,3 STMIK PalComTech \\ e-mail: ${ }^{1}$ denimarta61@gmail.com, 2 angga.palcomtech2014@gmail.com, \\ 3guntoro@palcomtech.ac.id
}

\begin{abstract}
ABSTRAK
Komputasi awan memberikan kemudahan dan kenyamanan pada setiap layanannya. Infrastructure as a Service merupakan salah satu layanan komputasi awan yang menjadi pilihan beberapa pengguna, sangat penting untuk mengetahui performa dari masing-masing platform yang ada agar mendapatkan hasil maksimal sesuai dengan kebutuhan kita. Dalam penelitian ini, menguji 3 platform penyedia layanan cloud computing yaitu VMWare ESXi, XenServer, dan Proxmox, dengan menggunakan metode penelitian tindakan. Dari hasil pengukuran performa yang dilakukan, kemudian dianalisis dan dibandingkan dengan batas minimal dan maksimal. Indikator yang diuji yaitu response time, throughput, dan resource-utilization sebagai perbandingan implementasi performa virtualisasi server. Pada pengujian resource utilization saat kondisi menginstall sistem operasi, penggunaan CPU pada platform Proxmox menunjukan penggunaan terendah yaitu $10,72 \%$, dan penggunaan RAM terendah yaitu 53,32\% juga pada platform Proxmox. Pada pengujian resource utilization saat kondisi idle menunjukan penggunaan terendah yaitu $5,78 \%$ pada platform Proxmox, Sedangkan penggunaan RAM terendah yaitu 57,25\% pada platform VMWare ESXi. Pengujian resource utilization rata-rata menunjukan bahwa platform Proxmox lebih baik. Pada pengujian throughput saat pengukuran upload dari platform XenServer lebih baik yaitu 1,37 MB/s, sedangkan pengujian throughput saat pengukuran download platform VMWare ESXi lebih baik yaitu 1,39 MB/s. Pada pengujian response time menunjukan platform VMWare ESXi sebagai yang tercepat yaitu $0,180 \mathrm{sec}$.
\end{abstract}

Kata kunci: Infrastructure as a Service, Proxmox, VMWare ESXi, XenServer, Action Research.

\begin{abstract}
Cloud Computing provides convenience and comfort to every service. Infrastructure as a Service is one of the cloud computing services that is a choice of several users, it is very important to know the performance of each existing platform in order to get the maximum result according to our needs. In this study, testing 3 platforms of cloud computing service providers are VMWare ESXi, XenServer, and Proxmox, using action research methods. From the results of performance measurements, then analyzed and compared with the minimum and maximum limits. The tested indicators are response time, throughput, and resource-utilization as a comparison of server virtualization performance implementations. In the resource utilization testing when the condition of installing an operating system, CPU usage on the Proxmox platform shows the lowest usage of $10.72 \%$, and the lowest RAM usage of $53.32 \%$ also on the Proxmox platform. In the resource test utilization when idle state shows the lowest usage of $5.78 \%$ on the Proxmox platform, while the lowest RAM usage is $57.25 \%$ on the VMWare ESXi platform. The mean resource utilization tests indicate that the Proxmox platform is better. At the throughput test when the upload measurement of the XenServer platform is better $1.37 \mathrm{MB} / \mathrm{s}$, while the throughput test when the download of the VMWare ESXi platform is better than $1.39 \mathrm{MB} / \mathrm{s}$. On response time testing shows the platform VMWare ESXi as the fastest is $0.180 \mathrm{sec}$.
\end{abstract}

Keywords: Infrastructure as a Service, Proxmox, VMWare ESXi, XenServer, Action Research.

Author Korespondensi (Guntoro Barovih)

Email:guntoro@palcomtech.ac.id 


\section{PENDAHULUAN}

Komputer adalah sebuah mesin yang pada dasarnya digunakan untuk menyelesaikan perhitungan matematis atau komputasi matematis. Pesatnya perkembangan teknologi saat ini berakibat pada kurangnya pemanfaatan komputer dengan kapasitas teknologi, memori, dan kecepatan prosesor yang kecil. Kebutuhan akan sumber daya komputer dengan skala besar menghasilkan beberapa metode komputasi, salah satunya adalah cloud computing.

Cloud computing memberikan kemudahan dan kenyamanan pada setiap layanannya. Layanan-layanan pada cloud computing yaitu Infrastructure as a Service, Platform as a Service, dan Software as a Service[1]. Infrastructure as a Service merupakan salah satu layanan cloud computing yang menjadi pilihan beberapa pengguna dimana mereka mendapat akses penuh terhadap hardware secara virtual : CPU, RAM, dan Disk Storage. Penggunaan Infrastructure as a Service mencakup berbagai bidang diantaranya bidang bisnis, karena perusahaan yang menggunakan layanan tersebut tidak perlu memikirkan biaya perawatan server, inilah kelebihan yang ditawarkan oleh pengelolah Infrastructure as a Service.

Virtualisasi adalah sebuah teknologi yang memungkinkan kita tidak melihat secara nyata spesifikasi yang ada didalamnya seperti sistem operasi, storage data, memori dan bahkan bandwidth[2]. Teknologi virtualisasi merupakan penggunaan perangkat lunak yang memungkinkan satu perangkat keras untuk mengoperasikan beberapa sistem operasi dan service lainnya pada saat bersamaan, dengan tujuan mengoptimalkan penggunaan prosesor dan menghidari pemborosan daya listrik serta pengeluaran biaya yang berlebihan untuk server. Virtualisasi server ada yang bersifat open source dan berbayar, diantaranya Proxmox, VMWare, dan XenServer. Dari beberapa platform tersebut tentunya terdapat beberapa perbedaan mulai dari fitur atau fasilitas dan yang paling utama adalah performa. Maka dari itu, sangat penting untuk mengetahui performa dari platform Proxmox, VMWare, dan XenServer dengan indikator response time, throughput, dan resource utilization sejauh mana kemampuan dari masing masing platform tersebut dalam menjalankan virtualisasi agar dapat menjadi referensi dalam memilih virtual server yang cocok untuk diimplementasikan baik bagi perusahaan atau individual atau perorangan.

Penelitian [3] berhasil membangun sebuah private cloud computing dengan layanan Infrastucture as a Service (IaaS), hasil dari pengujiannya didapatkan presentasi pencapaian kinerja turnaround time, response time, dan throughput sebesar $9.03 \%, 8.55 \%$, dan $0.35 \%$ sedangkan resource sebuah mesin server hingga penggunaan CPU mencapai $100 \%$ pada seluruh core dan penggunaan memori meningkat sebanyak 178 MB dengan jumlah mesin virtual yang dibuat didalam satu node sebanyak sepuluh. Penelitian [4] berhasil membandingkan server virtual dan server konvensional dengan hasil response time 7,6 ms, turnaround time 39,964 dan throughput $61,7 \mathrm{~KB} / \mathrm{s}$. Pada penelitian ini penulis menghasilkan sebuah rekomendasi untuk menentukan jumlah server virtual yang bisa dibuat dalam sebuah server cloud dengan layanan IAAS dengan catatan server penyedia layanan sesuai dengan spesifikasi yang telah ditentukan sebelumnya. Sedangkan peneliti [4] merencanakan penelitian menggunakan metode Action Research yang merupakan dapat digunakan sebagai penelitian pada bidang pendidikkan dan berhasil mengetahui kualitas layanan internet dengan parameter QoS (Quality of Services) yang terdiri dari delay dan packet loss sangat berpengaruh terhadap kinerja jaringan yang ada di SMK Negeri 1 Bangkinang Kapasitas bandwidth juga berpengaruh terhadap nilai QoS. Seperti yang telah diamati kecepatan transfer data nilai rata-rata tertinggi terjadi di lab TKJ yaitu 10,7 kbps. Penulis mengambil beberapa indikator pengujian dari penelitan yang dilakukan peneliti [3] dan [5] serta perencanaan metode dari peneliti [4] yaitu response time, throughput, dan resource utilization dengan platform yang diuji yaitu Proxmox, VMWare ESXi, dan XenServer menggunakan metode action research.

Proxmox adalah sebuah distro linux virtualisasi berbasis Debian yang mengusung OpenZV dan KVM. Proxmox memungkinkan untuk melakukan manajemen terpusat dari banyak server fisik [6][7]. VMWare atau jika diartikan apa adanya menurut kata-kata adalah 
perangkat mesin virtual. VMWare adalah aplikasi yang sudah cukup matang dan sangat terpercaya untuk melayani lingkungan tidak nyata (virtual) terhadap solusi komputerisasi. XenServer adalah open source virtual machine manager dan monitor, dikembangkan oleh University of Cambridge. Dibuat dengan tujuan untuk menjalankan sampai dengan seratus sistem operasi berfitur penuh (full feature $O S$ ) di hanya satu komputer. Virtualisasi XenServer menggunakan teknologi paravirtualisasi menyediakan isolasi yang aman, pengaturan sumber daya, garansi untuk quality-of-services, dan live migration untuk sebuah mesin virtual[8][9].

\section{METODOLOGI}

Metode penelitian yang penulis gunakan adalah action research atau penelitian tindakan. Action research sebagai metode penelitian yang didirikan atas asumsi bahwa teori dan praktek dapat secara tertutup diintegrasikan dengan pembelajaran dari hasil intervensi yang direncanakan setelah diagnosis yang rinci terhadap konteks masalah[10]. Tahapantahapan metode action research dapat dilihat pada gambar 1 .

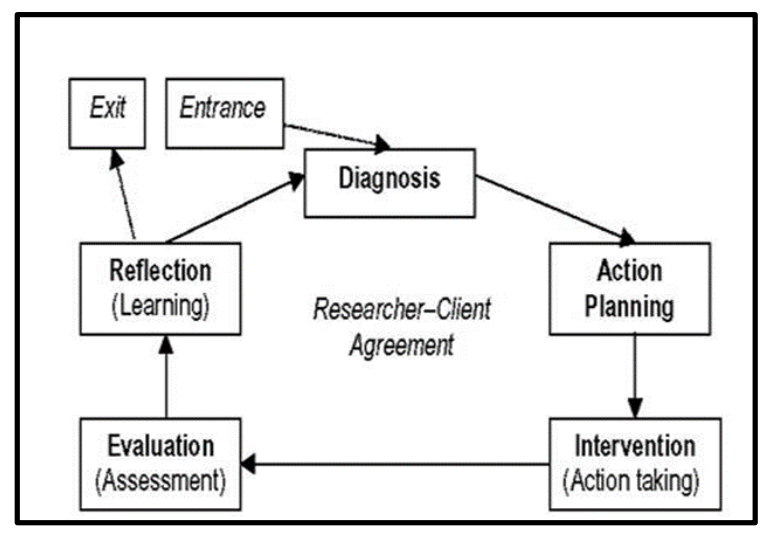

Gambar 1. Tahapan Metode Action Research[10]

\section{HASIL DAN PEMBAHASAN}

\section{A. Hasil}

\section{Diagnosis}

Pada tahap ini penulis memilih perangkat yang dibutuhkan dalam melakukan penelitian baik perangkat keras maupun perangkat lunak dapat dilihat pada tabel 1 .
Tabel 1. Perangkat Keras dan Perangkat Lunak yang Digunakan

\begin{tabular}{|c|c|}
\hline Perangkat Keras & Perangkat Lunak \\
\hline $\begin{array}{lr}\text { Processor } & \text { Intel }(R) \\
\text { Core }(T M) & \text { i5-4440 } \\
3.10 \mathrm{GHz} & \text { sebagai PC } \\
\text { Server } & \end{array}$ & Proxmox VE 5.2 \\
\hline RAM 8 GB & VMWare ESXi 6.7 \\
\hline HDD 500GB 7200rpm & XenServer 7.6 \\
\hline Kabel UTP & Ubuntu 16.04.4 LTS \\
\hline Switch 16 Port & $\begin{array}{lrr}\text { Windows } & \text { dan } & \text { Linux } \\
\text { sebagai } & & \text { Sistem } \\
\text { Operasi } & & \\
\end{array}$ \\
\hline Laptop sebagai Client & Wireshark 2.6.6 \\
\hline & Siege 3.0.5 \\
\hline
\end{tabular}

\section{Action Planing}

Untuk mendapatkan hasil yang diinginkan, peneliti akan melakukan pengujian dan pengamatan terhadap resource utilization, throughput, dan response time. Teknik pengujiannya sebagai berikut :

1. Pengujian resource-utilization, mencatat persentase penggunaan CPU dan memori pada saat penginstallan file ISO berupa sistem operasi ke dalam virtual machine secara bersamaan, 1 user menginstall 1 sistem operasi ke dalam virtual machine (VM). Penginstallan dimulai dari $2 \mathrm{VM}, 4 \mathrm{VM}, 6$ $\mathrm{VM}, 8 \mathrm{VM}, 10 \mathrm{VM}, 12 \mathrm{VM}, 14 \mathrm{VM}$, dan 16 VM yang mana setiap detik perubahan yang terjadi akan dicatat hingga penginstallan selesai serta pada saat virtual machine kondisi idle tanpa adanya proses apaun pada masingmasing platform selama 60 detik.

2. Pengujian throughput, 10 client melakukan transfer data berupa upload dan download file sebesar $100 \mathrm{MB}$ pada setiap virtual machine di masing-masing platform kemudian hasilnya akan dihitung menggunakan perhitungan throughput.

3. Pengujian response time, dilakukan dengan menguji virtual machine pada platform Proxmox, VMWare, dan XenServer dengan memberikan request sebanyak 1000 request oleh 10 client dan mencatat waktu yang dibutuhkan mesin dalam memproses requestrequest tersebut. 


\section{Action Tacking}

Pada tahapan ini, peneliti melakukan pengujian resource utilization, throughput, dan response time. Dibawah ini penjelasan dari pengujian-pengujian yang dilakukan yaitu :

1. Pengujian resource utilization pada ESXi, XenServer, dan Proxmox mulai dari 2 VM, 4 $\mathrm{VM}, 6 \mathrm{VM}, 8 \mathrm{VM}, 10 \mathrm{VM}, 12 \mathrm{VM}, 14 \mathrm{VM}$, dan 16 VM. Yang mana setiap virtual machine diuji dengan menginstall sistem operasi pada virtual machine untuk 1 user menginstall 1 sistem operasi dan pada saat kondisi idle tanpa melakukan proses apapun, hasilnya berupa perbandingan persentase dari penggunaan CPU dan RAM dari masing-masing platform sampai dengan installasi pada virtual machine selesai. Pencatatan persentase CPU dan RAM yang digunakan dapat dilihat dari fitur monitoring yang disediakan oleh masing-masing platform dapat dilihat pada gambar 2, gambar 3, dan gambar 4 :

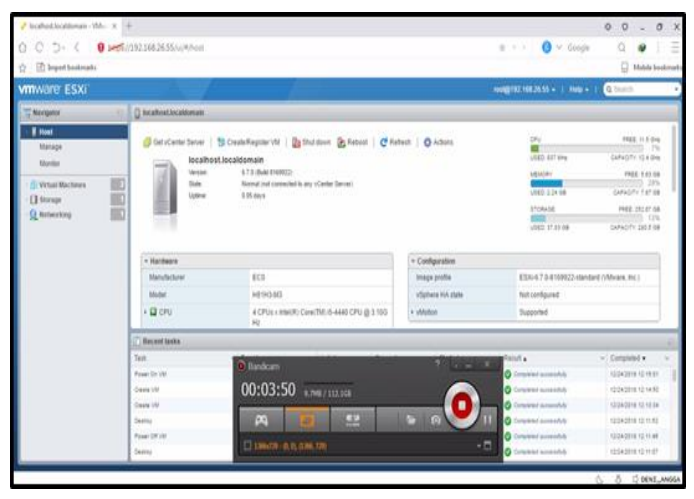

Gambar 2. Monitoring pada VMWare ESXi

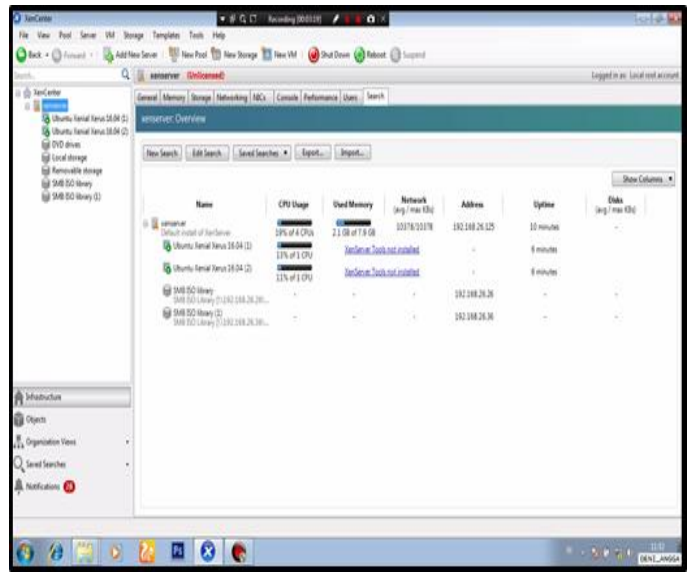

Gambar 3. Monitoring pada XenServer

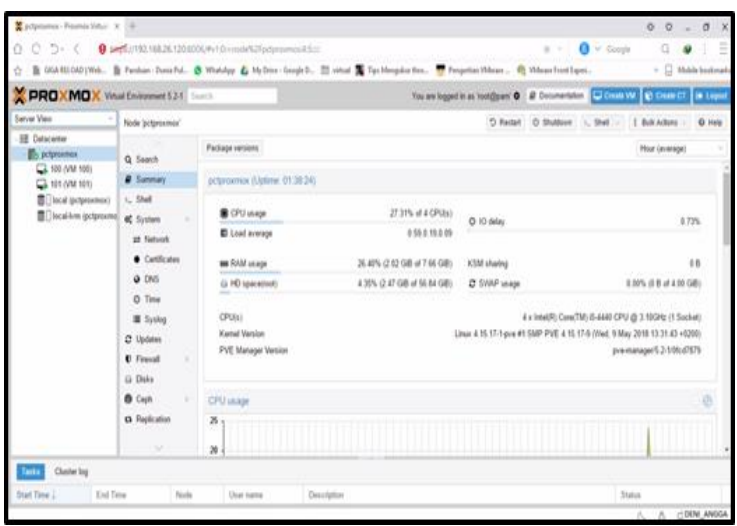

Gambar 4. Monitoring pada Proxmox

2. Pengujian throughput pada ESXi, Proxmox, dan XenServer dengan melakukan proses transfer data berupa upload dan download file berukuran $100 \mathrm{MB}$ oleh 10 client secara bersamaan pada virtual machine. Peneliti menggunakan Owncloud sebagai sarana transfer data dan Wireshark sebagai software yang memonitor paket dan waktu yang diperlukan dalam transfer data, pengujian dilakukan oleh 10 client pada 7 virtual machine dan hasilnya nanti akan dibandingkan throughput dari setiap virtual machine dari masing-masing platform. Salah satu bukti pengujian throughput upload dan download menggunakan wireshark dapat dilihat pada gambar 5.

\begin{tabular}{|c|c|c|c|c|}
\hline \multicolumn{5}{|l|}{ Interfaces } \\
\hline Interface & Dropoed packets & Capture fiter & Link type & $\frac{\text { Packet }}{\text { size linit }}$ \\
\hline \multicolumn{2}{|c|}{$\begin{array}{l}\text { Device } 0(0 \%) \\
\text { WPF_\{7FD406AF-0178-42FE- } \\
\text { A355-86C9A1287036\} }\end{array}$} & none & Ethernet & $\begin{array}{l}65535 \\
\text { bytes }\end{array}$ \\
\hline \multicolumn{5}{|l|}{ Statistics } \\
\hline Measurement & Captured & Displayed & Marked & \\
\hline Packets & 110655 & $110655(100.0 \%)$ & - & \\
\hline Time span, s & 175.391 & 175.391 & - & \\
\hline Average pps & 630.9 & 630.9 & - & \\
\hline Average packet size, B & 1004 & 1004 & - & \\
\hline Bytes & 111146436 & $111146436(100.0 \%)$ & 0 & \\
\hline Average bytes/s & $633 \mathrm{k}$ & $633 \mathrm{k}$ & - & \\
\hline Average bits/s & $5069 \mathrm{k}$ & $5069 \mathrm{k}$ & - & \\
\hline \multicolumn{5}{|l|}{ Interfaces } \\
\hline Interface & Dropped packets & Capture fiter & Link type & $\frac{\text { Packet }}{\text { size Imit }}$ \\
\hline $\begin{array}{l}\text { Device } \\
\text { WPF_\{TRD 406AF-0173- } \\
\text { A355-86C9A12B } 7036\}\end{array}$ & -42 EE. $0(0 \%)$ & none & Ethernet & $\begin{array}{l}65535 \\
\text { bytes }\end{array}$ \\
\hline \multicolumn{5}{|l|}{ Statistics } \\
\hline Measurement & Captured & Displayed & \multicolumn{2}{|l|}{ Marked } \\
\hline Packets & 109657 & $109657(100.0 \%)$ & - & \\
\hline Time span, s & 126.552 & 126.552 & - & \\
\hline Average pps & 866.5 & 866.5 & \multirow{2}{*}{-} & \\
\hline Average packet size, B & 1011 & 1011 & & \\
\hline Bytes & 110866140 & $110866140(100.0 \%)$ & $\bar{a}$ & \\
\hline Average bytes/s & $876 k$ & $876 k$ & \multirow{2}{*}{$\begin{array}{l}- \\
-\end{array}$} & \\
\hline Average bits/s & $7008 \mathrm{k}$ & $7008 \mathrm{k}$ & & \\
\hline
\end{tabular}

Gambar 5. Pengujian Throughput Menggunakan Wireshark 
3. Pengujian response time pada ESXi, XenServer, dan Proxmox dengan 10 client secara bersamaan melakukan 1000 request ke virtual machine. Pengujian dilakukan pada 7 virtual machine dan hasilnya berupa waktu yang akan dibandingan antar platform tersebut. Salah satu bukti pengujian response time menggunakan siege dapat dilihat pada gambar 6.

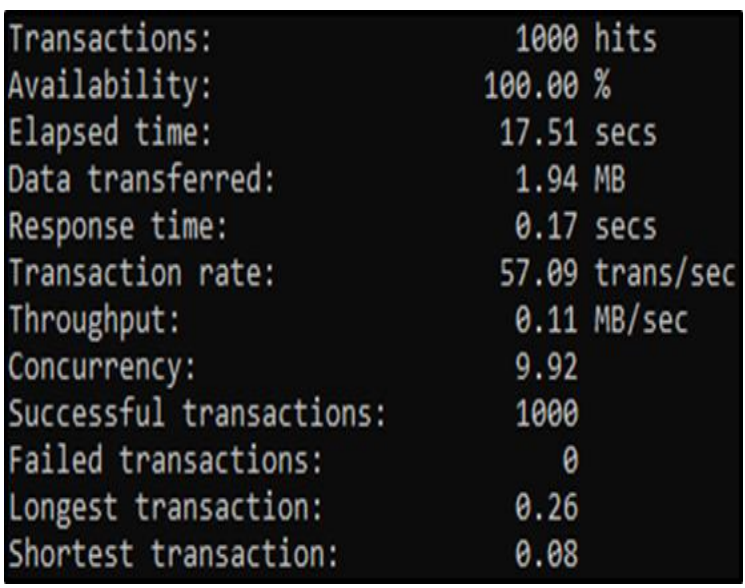

Gambar 6. Pengujian Response Time Menggunakan Siege

\section{Evaluation}

Pada tahapan evaluation, hasil dari pengujian perbandingan performa antara platform VMWare ESXi, XenServer, dan Proxmox akan diringkas. Hasil ringkasan pengujian resource utilization, throughput, dan response time dapat dilihat pada tabel 2 , tabel 3 , dan tabel 4.

Tabel 2. Hasil Ringkasan Pengujian Resource Utilization (sample : install os pada vm besamaan dan kondisi idle)

\begin{tabular}{|c|c|c|c|c|c|c|}
\hline \multirow[b]{2}{*}{$\begin{array}{c}\text { Rincia } \\
\text { n uji }\end{array}$} & \multicolumn{2}{|c|}{$\begin{array}{c}\text { VMWare } \\
\text { ESXi }\end{array}$} & \multicolumn{2}{|c|}{$\begin{array}{c}\text { XenServe } \\
\mathbf{r}(\mathrm{XS})\end{array}$} & \multicolumn{2}{|c|}{$\begin{array}{c}\text { Proxmox } \\
\text { (PVE) }\end{array}$} \\
\hline & $\begin{array}{c}\text { CP } \\
\mathbf{U} \\
(\% \\
)\end{array}$ & $\begin{array}{c}\text { RA } \\
\text { M } \\
(\%)\end{array}$ & $\begin{array}{c}\mathbf{C P} \\
\mathbf{U} \\
(\% \\
)\end{array}$ & $\begin{array}{c}\text { RA } \\
\text { M } \\
(\% \\
)\end{array}$ & $\begin{array}{c}\mathbf{C P} \\
\mathbf{U} \\
(\% \\
)\end{array}$ & $\begin{array}{c}\text { RA } \\
\text { M } \\
(\%)\end{array}$ \\
\hline $\begin{array}{l}2 V M \\
\text { bersa } \\
\text { man }\end{array}$ & $\begin{array}{c}8,8 \\
7\end{array}$ & $\begin{array}{c}26,9 \\
1\end{array}$ & $\begin{array}{l}18, \\
93\end{array}$ & $\begin{array}{l}22, \\
06\end{array}$ & $\begin{array}{c}8,4 \\
9\end{array}$ & $\begin{array}{c}21,3 \\
7\end{array}$ \\
\hline $\begin{array}{l}2 V M \\
\text { idle }\end{array}$ & $\begin{array}{l}11, \\
88\end{array}$ & $\begin{array}{c}27,2 \\
0\end{array}$ & $\begin{array}{l}11, \\
90\end{array}$ & $\begin{array}{l}26, \\
60\end{array}$ & $\begin{array}{c}3,1 \\
3\end{array}$ & $\begin{array}{c}32,0 \\
0\end{array}$ \\
\hline $\begin{array}{l}4 \mathrm{VM} \\
\text { bersa } \\
\text { man }\end{array}$ & $\begin{array}{c}7,9 \\
2\end{array}$ & $\begin{array}{c}31,8 \\
0\end{array}$ & $\begin{array}{c}26, \\
16\end{array}$ & $\begin{array}{c}38, \\
11\end{array}$ & $\begin{array}{c}8,0 \\
2\end{array}$ & $\begin{array}{c}32,6 \\
3\end{array}$ \\
\hline
\end{tabular}

\begin{tabular}{|c|c|c|c|c|c|c|}
\hline $\begin{array}{l}\text { 4VM } \\
\text { idle }\end{array}$ & $\begin{array}{l}11, \\
35\end{array}$ & $\begin{array}{c}42,0 \\
0\end{array}$ & $\begin{array}{l}11, \\
13\end{array}$ & $\begin{array}{l}39, \\
20\end{array}$ & $\begin{array}{c}1,8 \\
3\end{array}$ & $\begin{array}{c}46,0 \\
0\end{array}$ \\
\hline $\begin{array}{l}6 V M \\
\text { bersa } \\
\text { man }\end{array}$ & $\begin{array}{l}10, \\
12\end{array}$ & $\begin{array}{c}47,6 \\
5\end{array}$ & $\begin{array}{l}30, \\
61\end{array}$ & $\begin{array}{l}51, \\
13\end{array}$ & $\begin{array}{c}9,6 \\
2\end{array}$ & $\begin{array}{c}51,9 \\
3\end{array}$ \\
\hline $\begin{array}{l}6 V M \\
\text { idle }\end{array}$ & $\begin{array}{l}19 \\
60\end{array}$ & $\begin{array}{c}55,0 \\
0\end{array}$ & $\begin{array}{l}17, \\
68\end{array}$ & $\begin{array}{l}51, \\
90\end{array}$ & $\begin{array}{c}7,2 \\
2\end{array}$ & $\begin{array}{c}76,0 \\
0\end{array}$ \\
\hline $\begin{array}{l}8 V M \\
\text { bersa } \\
\text { man }\end{array}$ & $\begin{array}{c}13, \\
91\end{array}$ & $\begin{array}{c}67,6 \\
8\end{array}$ & $\begin{array}{l}27, \\
76\end{array}$ & $\begin{array}{l}61, \\
98\end{array}$ & $\begin{array}{l}13, \\
04\end{array}$ & $\begin{array}{c}76,1 \\
4\end{array}$ \\
\hline $\begin{array}{l}8 V M \\
\text { idle }\end{array}$ & $\begin{array}{l}19, \\
92\end{array}$ & $\begin{array}{c}63,5 \\
7\end{array}$ & $\begin{array}{l}12, \\
67\end{array}$ & $\begin{array}{l}64, \\
60\end{array}$ & $\begin{array}{c}7,3 \\
2\end{array}$ & $\begin{array}{c}76,0 \\
0\end{array}$ \\
\hline $\begin{array}{l}10 \mathrm{VM} \\
\text { bersa } \\
\text { man }\end{array}$ & $\begin{array}{c}9,7 \\
2\end{array}$ & $\begin{array}{c}61,7 \\
4\end{array}$ & $\begin{array}{l}28, \\
48\end{array}$ & $\begin{array}{l}75, \\
07\end{array}$ & $\begin{array}{l}11, \\
56\end{array}$ & $\begin{array}{c}66,7 \\
7\end{array}$ \\
\hline $\begin{array}{l}10 V M \\
\text { idle }\end{array}$ & $\begin{array}{c}4,2 \\
7\end{array}$ & $\begin{array}{c}66,0 \\
0\end{array}$ & $\begin{array}{l}14, \\
17\end{array}$ & $\begin{array}{l}77, \\
20\end{array}$ & $\begin{array}{c}9,1 \\
7\end{array}$ & $\begin{array}{c}70,8 \\
4\end{array}$ \\
\hline $\begin{array}{l}12 \mathrm{VM} \\
\text { bersa } \\
\text { man }\end{array}$ & $\begin{array}{l}14, \\
84\end{array}$ & $\begin{array}{c}84,8 \\
8\end{array}$ & $\begin{array}{l}32, \\
63\end{array}$ & $\begin{array}{l}86, \\
35\end{array}$ & $\begin{array}{l}13, \\
60\end{array}$ & $\begin{array}{c}71,0 \\
9\end{array}$ \\
\hline $\begin{array}{l}12 V M \\
\text { idle }\end{array}$ & $\begin{array}{c}9,2 \\
7\end{array}$ & $\begin{array}{c}89,7 \\
3\end{array}$ & $\begin{array}{l}13, \\
83\end{array}$ & $\begin{array}{l}89, \\
90\end{array}$ & $\begin{array}{c}6,0 \\
0\end{array}$ & $\begin{array}{c}79,4 \\
7\end{array}$ \\
\hline
\end{tabular}

Tabel 3. Hasil Ringkasan Pengujian Throughput (10 client upload/download)

\begin{tabular}{|l|c|c|c|c|c|c|}
\hline \multirow{2}{*}{$\begin{array}{c}\text { Rinc } \\
\text { ian } \\
\text { uji }\end{array}$} & \multicolumn{4}{|c|}{ Throughput (MB/s) } \\
\cline { 2 - 7 } & $\begin{array}{c}\text { ESX } \\
\text { i }\end{array}$ & $\begin{array}{c}\text { PV } \\
\text { E }\end{array}$ & $\mathbf{X S}$ & $\begin{array}{c}\text { ES } \\
\text { Xi }\end{array}$ & $\begin{array}{c}\text { PV } \\
\text { E }\end{array}$ & XS \\
\hline $\mathrm{Ke} 1$ & 1,10 & 1,1 & 1,6 & 0,8 & 0,7 & 1,3 \\
$V M$ & 2 & 54 & 45 & 37 & 05 & 26 \\
\hline $\mathrm{Ke} 2$ & 0,60 & 0,9 & 1,6 & 1,2 & 1,6 & 1,2 \\
$V M$ & 8 & 34 & 05 & 18 & 09 & 47 \\
\hline $\mathrm{Ke} 3$ & 0,98 & 1,0 & 1,2 & 2,2 & 0,9 & 1,2 \\
$V M$ & 4 & 43 & 16 & 62 & 4 & 72 \\
\hline $\mathrm{Ke} 4$ & 0,57 & 0,9 & 1,4 & 1,4 & 1,7 & 1,2 \\
$V M$ & 3 & 19 & 47 & 47 & 31 & 07 \\
\hline $\mathrm{Ke} 5$ & 1,10 & 0,8 & 1,1 & 1,9 & 0,9 & 1,2 \\
$V M$ & 9 & 9 & 48 & 02 & 9 & 74 \\
\hline $\mathrm{Ke} 6$ & 0,82 & 0,8 & 1,1 & 1,1 & 0,8 & 0,7 \\
$V M$ & 2 & 15 & 35 & 55 & 33 & 62 \\
\hline $\mathrm{Ke} 7$ & $V M$ & 1,2 & 1,3 & 0,9 & 0,9 & 0,7 \\
$V M$ & & 01 & 90 & 13 & 19 & 92 \\
\hline
\end{tabular}

Tabel 4. Hasil Ringkasan Pengujian Response Time (1000 Request)

\begin{tabular}{|l|c|c|c|}
\hline \multirow{2}{*}{$\begin{array}{c}\text { Rincian } \\
\text { Penguji } \\
\text { an }\end{array}$} & \multicolumn{3}{|c|}{ Response Time (sec) } \\
\cline { 2 - 4 } & $\begin{array}{c}\text { VMWa } \\
\text { reESXi }\end{array}$ & $\begin{array}{c}\text { Proxm } \\
\text { ox }\end{array}$ & $\begin{array}{c}\text { Xen } \\
\text { Server }\end{array}$ \\
\hline $1 V M$ & 0,17 & 0,19 & 0,21 \\
\hline $2 V M$ & 0,18 & 0,18 & 0,2 \\
\hline
\end{tabular}




\begin{tabular}{|l|c|c|c|}
\hline $3 V M$ & 0,21 & 0,19 & 0,2 \\
\hline $4 V M$ & 0,19 & 0,2 & 0,2 \\
\hline $5 V M$ & 0,17 & 0,19 & 0,2 \\
\hline $6 V M$ & 0,17 & 0,2 & 0,21 \\
\hline $7 V M$ & 0,17 & 0,19 & 0,21 \\
\hline
\end{tabular}

\section{Reflection}

Pada tahapan ini, peneliti melakukan pengumpulan data hasil pengujian yang telah dilakukan yang kemudian dilakukan perbandingan performa berdasarkan kriteria pengujian yang akan disajikan dalam bentuk grafik untuk mempermudah dalam melakukan analisa dalam mencari permasalahan perbedaan performa tersebut.

\section{B. Pembahasan}

\section{Perbandingan Resource Utilization ESXi, XenServer, dan Proxmox.}

Perbandingan dengan indikator resource utilization dibagi menjadi 2 pengujian, yaitu pada kondisi virtual server dibebani dengan menginstall sistem operasi dan pada kondisi idle tanpa melakukan apapun dapat dilihat pada gambar 7. dan gambar 8 .

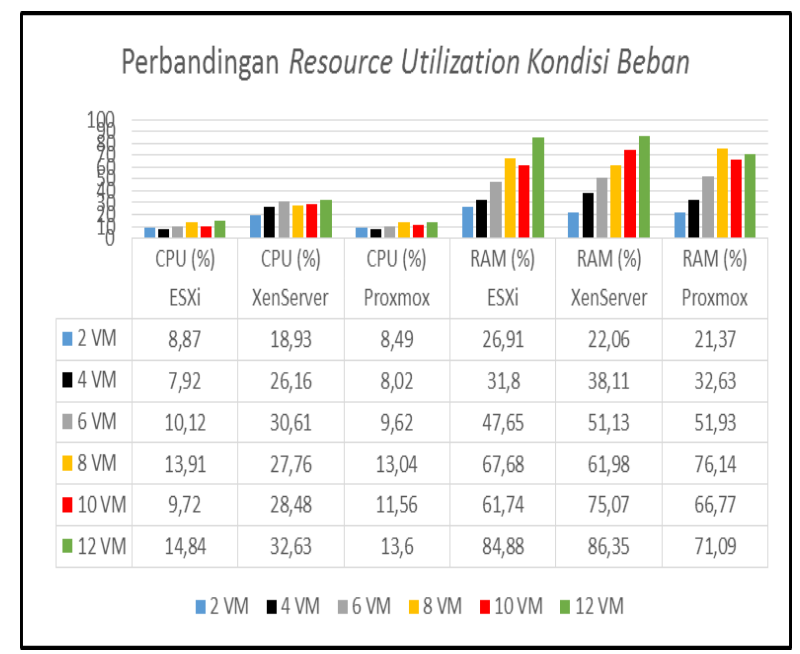

Gambar 7. Grafik Perbandingan Resource Utilization Kondisi Beban

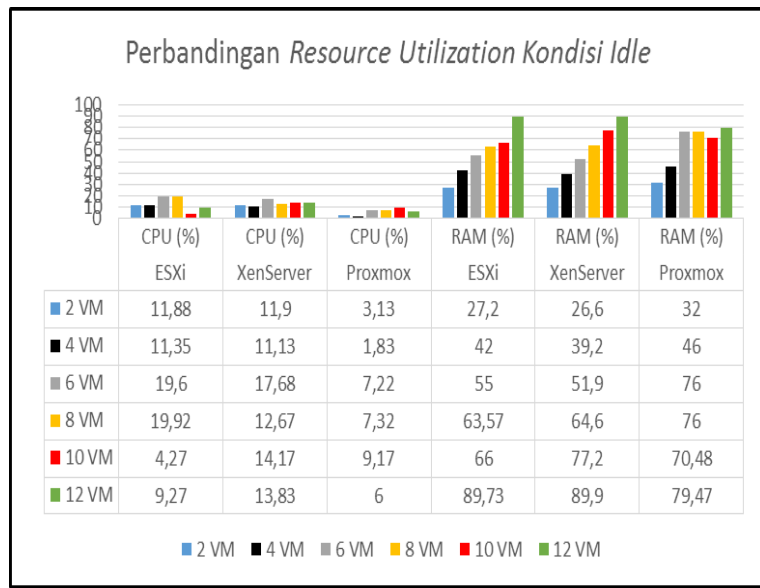

Gambar 8. Grafik Perbandingan Resource Utilization Kondisi Idle

Gambar 7. menjelaskan tentang grafik dari hasil pengujian resource utilization pada kondisi menginstall sistem operasi. Rata-rata penggunaan CPU dari VMWare ESXi, XenServer, dan Proxmox yaitu $10,90 \%, 27,43 \%$, dan $10,72 \%$. Sedangkan penggunaan RAM yaitu $53,44 \%$, $55,78 \%$, dan $53,32 \%$. Dari grafik tersebut terlihat penggunaan CPU dan RAM pada Proxmox lebih baik karena penggunaan CPU dan RAM yang kecil dibandingkan VMWare ESXi dan XenServer yaitu $10,72 \%$ dan $53,32 \%$.

Gambar 8. menjelaskan tentang grafik dari hasil pengujian pengujian resource utilization pada kondisi idle tanpa melakukan apapun. Ratarata penggunaan CPU dari VMWare ESXi, XenServer, dan Proxmox yaitu 12,72\%, 13,56\%, $5,78 \%$. Sedangkan penggunaan RAM yaitu $57,25 \%, 58,23 \%, 63,33 \%$. Dari grafik tersebut terlihat penggunaan CPU dari Proxmox lebih baik yaitu $5,78 \%$, dan untuk penggunaan RAM VMWare EXSi lebih baik yaitu 57,25\%.

\section{Perbandingan Throughput ESXi, XenServer, dan Proxmox.}

Perbandingan throughput ini didapatkan dari 10 client yang melakukan upload dan download pada virtual machine yang telah di install owncloud. Untuk lebih jelas hasil perbandingannya dapat dilihat tabel 9 . 


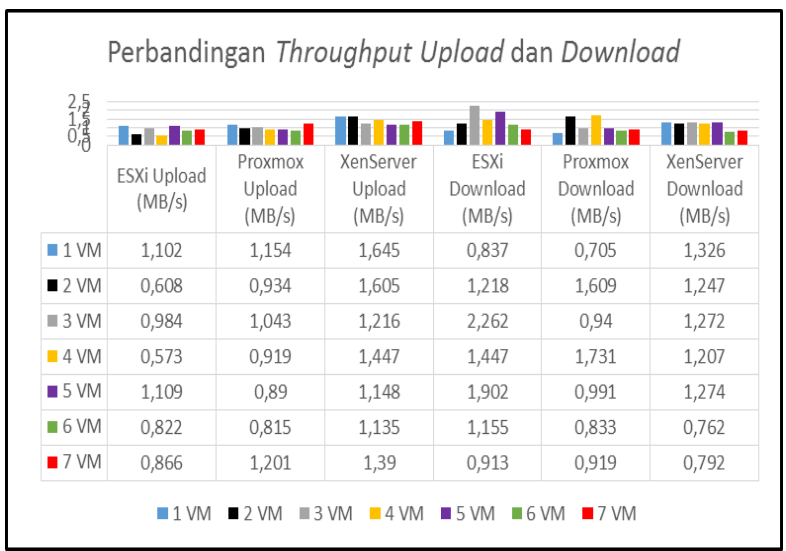

Gambar 9. Grafik Perbandingan Throughput Upload dan Download

Gambar 9. menjelaskan tentang grafik dari hasil perbandingan throughput upload dan download yang dilakukan oleh 10 client. Ratarata hasil throughput upload pada platform VMWare ESXi, Proxmox, dan XenServer yaitu $0,886 \mathrm{MB} / \mathrm{s}, 0,994 \mathrm{MB} / \mathrm{s}$, dan $1,369 \mathrm{MB} / \mathrm{s}$. Sedangkan hasil throughput download yaitu $1,391 \mathrm{MB} / \mathrm{s}, 1,104 \mathrm{MB} / \mathrm{s}$, dan 1,126 MB/s. Dari grafik tersebut terlihat throughput upload dari XenServer lebih baik yaitu 1,369 MB/s, sedangkan throughput download VMWare ESXi lebih baik yaitu 1,391 MB/s.

\section{Perbandingan Response Time VMWare ESXi, XenServer, dan Proxmox}

Perbandingan response time dari VMWare ESXi, Proxmox, dan XenServer yaitu 10 client melakukan 1000 request kepada virtual machine dapat dilihat pada gambar 10.

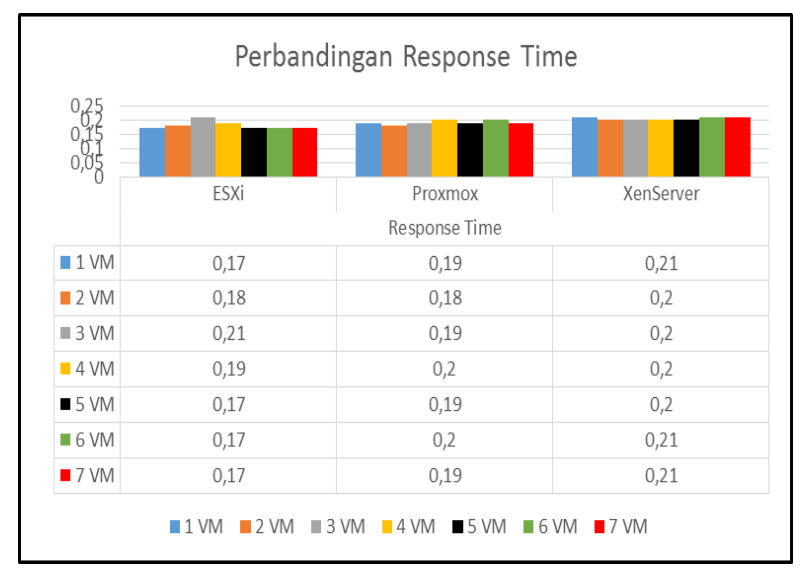

Gambar 10. Grafik Perbandingan Response Time

Gambar 10. menjelaskan tentang hasil dari perbandingan response time yang mana dilakukan 1000 request oleh 10 client terhadap virtual server dari platform VMWare ESXi, Proxmox, dan XenServer. Rata-rata hasil perbandingan response time dari VMWare ESXi, Proxmox, dan XenServer yaitu 0,180 sec, 0,191 sec, dan 0,204. Dari grafik tersebut dapat dilihat response time dari VMWare ESXi lebih baik karena waktu yang dibutuhkan untuk merespon request yang diberikan lebih kecil dibandingkan dengan Proxmox dan XenServer yaitu 0,180 sec.

\section{SIMPULAN DAN SARAN}

\section{Simpulan}

Dari hasil pengujian resource utilization pada kondisi menginstall sistem operasi, rata-rata penggunaan CPU dan RAM pada Proxmox lebih baik yaitu $10,72 \%$ dan $53,32 \%$. Ini dikarenakan fitur teknologi OpenVZ yang ada pada Proxmox, fitur ini berperan dalam membagi resource. Akan tetapi pada saat kondisi idle tanpa melakukan apapun, fitur ini tidak terlalu berperan dibuktikan dengan penggunaan RAM pada VMWare ESXi lebih baik yaitu $57,25 \%$ dari platform lainnya.

Pada pengujian resource utilization batas maksimal virtual machine yang dapat menginstall sistem operasi pada platform Proxmox lebih banyak yaitu dengan 16 virtual machine sedangkan platform VMWare ESXi dan XenServer dapat menampung hanya 12 virtual machine. Hal ini karena Proxmox menggunakan virtual memory untuk setiap virtual server.

Dari hasil perbandingan throughput upload dan download yang dilakukan oleh 10 client melakukan upload dan download file berukuran $100 \mathrm{MB}$, rata-rata throughput upload dari XenServer lebih baik yaitu 1,369 MB/s sedangkan throughput download VMWare ESXi lebih baik yaitu $1,391 \mathrm{MB} / \mathrm{s}$. Pada pengujian throughput ada beberaapa faktor yang menyebabkan cepat lambatnya proses transfer data diantranya yaitu antrian data pada saat melakukan transfer data secara bersamaan bahkan mengakibatkan error.

Perbandingan response time yang mana dilakukan 1000 request oleh 10 client, rata-rata hasil perbandingan response time VMWare ESXi lebih baik yaitu $0,180 \mathrm{sec}$ karena waktu yang dibutuhkan untuk merespon request yang diberikan lebih kecil. 


\section{Saran}

Saran yang bisa diberikan bagi peneliti berikutnya yang ingin melakukan penelitian serupa ataupun berhubungan dengan virtualisasi pada teknologi jaringan cloud. Sebaiknya perangkat teknologi pendukung cloud computing khususnya sistem server,sebaiknya menggunakan sistem koputer yang khusus untuk server agar hasil pengujian bisa di dapatkan secara maksimal serta bisa menggunakan parameter atau variabel pengujian yang lebih kompleks lagi.

\section{UCAPAN TERIMA KASIH}

Pada kesempatan kali ini, penulis menyampaikan penghargaan dan penghormatan kepada semua pihak yang telah membantu penulis dalam menyelesaikan penelitian ini. Ucapan terima kasih penulis sampaikan kepada

a. Kaprodi Teknik Informatika yang telah memberikan izin kepada penulis untuk menggunakan fasilitas laboratorium dalam membangun, mengimplementasikan dan melakukan pengujian sistem cloud yang penulis teliti.

b. Rekan-rekan mahasiswa sebagai responden yang telah meluangkan waktu untuk menguji sistem yang penulis teliti.

\section{REFERENSI}

[1] T. Fajrin, "Analisis Sistem Penyimpanan Data Menggunakan Sistem Cloud Computing Studi Kasus SMK N 2 Karanganyar," Indones. J. Netw. Secur. Vol.1, No. 1, vol. 1, no. November, hal. 31-35, 2012.

[2] B. Widayanto, R. Munadi, dan R. Mayasari, "Implementasi dan Analisis Perbandingan Performansi VoIP Server pada VPS Berbasis OpenVZ dan Cloud Computing," e-Proceeding Eng. , vol. 2, no. 2 Agustus, hal. 3195-3202, 2015.

[3] W. Arsa dan K. Mustofa, "Perancangan dan Analisis Kinerja Private Cloud Computing dengan Layanan InfrastructureAs-A-Service (IAAS), " (Indonesian J.
Comput. Cybern. Syst., vol. 8, no. 2, hal. 2013, 2013.

[4] H. Ramadhan, E. Saputra, dan M. Fronita, "Analisis Kinerja Jaringan Internet Menggunakan Metode RMA (Realibility, Maintainability And Availability) Dan QOS(Quality Of Service) (Studi Kasus: SMK Negeri 1 Bangkinang)," J. Rekayasa Dan Manaj. Sist. Inf., vol. 2, no. 2 Agustus, hal. 56-60, 2016.

[5] I. G. N. W. Arsa, "Perbandingan dan Rekomendasi Server Sebagai Penyedia Layanan Infrastruktur Cloud Computing," Semnasteknomedia online, vol. 6, no. 1 , Februari, hal. 7-12, 2018.

[6] O. W. Purbo, Membuat Sendiri Cloud Computing Server Menggunakan Open Source. Yogyakarta: Andi Publisher, 2012.

[7] A. Kovari dan P. Dukan, "KVM \& OpenVZ virtualization based IaaS open source cloud virtualization platforms: OpenNode, Proxmox VE," Jubil. Int. Symp. Intell. Syst. Informatics, SISY 2012, vol. 10, hal. 335339, 2012.

[8] Athailah, Buku Pintar Virtualisasi. Yogyakarta: Andi Offset, 2016.

[9] R. F. Aswariza, D. Perdana, dan R. M. Negara, "Analisis Throughput Dan Skalabilitas Virtualized Network Function VyOS Pada Hypervisor VMWare ESXi, XEN, DAN KVM," J. Infotel, vol. 9, no. 1, Februari, hal. 70, 2017.

[10] C. Mukmin, "Efisiensi Maintenance Laboratorium Komputer Berbasis Jaringan," Semin. Nas. Teknol. Informasi, Bisnis, dan Desain, hal. 102-105, 2017. 